\title{
The simultaneous estimation of the amounts of protozoal, bacterial and dietary nitrogen entering the duodenum of steers
}

\author{
BY J. E. COCKBURN AND A. P. WILLIAMS \\ National Institute for Research in Dairying, Shinfield, Reading, Berkshire RG2 9AT
}

(Received 19 July 1983 - Accepted 8 August 1983)

1. Four steers were given straw and tapioca diets, twice daily, in a $4 \times 4$ Latin-square design. These diets, containing $4.2 \mathrm{~g}$ nitrogen $/ \mathrm{kg}$ dry matter (DM), were further supplemented with either urea, decorticated groundnut meal (DCGM), untreated (UT) casein or formaldehyde-treated (FT) casein to give a total of $19.7 \mathrm{~g} \mathrm{~N} / \mathrm{kg} \mathrm{DM}$ and $10.5 \mathrm{MJ} / \mathrm{kg} \mathrm{DM}$ daily.

2. Concurrent samples of rumen bacteria and protozoa and abomasal digesta were collected for each period of the experiment and the concentrations of 2-aminoethyl phosphonic acid (AEPA), diaminopimelic acid (DAPA), total nitrogen (TN), total phosphorus (TP), amino acids and hexosamines were determined in the dried preparations. The nature of the dietary supplements had little effect on the concentrations of most of these constituents or on the total protozoal numbers.

3. Abomasal digesta samples marked with polyethylene glycol (PEG) and chromic oxide for flow estimation were collected over $24 \mathrm{~h}$, and the proportions of protozoal- $\mathrm{N}$, bacterial- $\mathrm{N}$ and microbial- $\mathrm{N}$ estimated simultaneously using the markers AEPA, DAPA and RNA respectively. These digesta-N components were also estimated using an amino acid profiling (AAP) method which gave, in addition, estimates of the dietary and endogenous components. For the diets containing casein, the proportion of dietary casein was estimated directly using casein-P as a marker.

4. Estimates of the respective mean proportions of microbial- $N$ in abomasal digesta non-ammonia-N (NAN) for the diets containing urea, DCGM, UT casein or FT casein were: AEPA $0.56,0.32,0.27$ and $0 \cdot 16$; DAPA $0 \cdot 88,0 \cdot 70,0.81$ and 0.57 ; RNA $0.98,0 \cdot 85,0.92$ and 0.53 .

5. Giving FT casein significantly $(P<0.001)$ increased the flow of casein- $N$ at the abomasum and a significantly $(P<0.001)$ greater proportion of casein-N was found in abomasal NAN $(0.51 v .0 .09)$ where FT rather than UT casein was given.

6. The AAP method gave results for the proportions of microbial- and dietary-N (where casein was given) which were, in general, slightly lower than those obtained using RNA and casein-P as markers. Agreement with estimates of bacterial protein (from DAPA) and of protozoal protein (from AEPA) was less satisfactory.

7. Comparisons of the various estimates of the proportions of microbial- $\mathrm{N}$ in abomasal digesta suggested that the results obtained for protozoal-N by AEPA were overestimates. AEPA was found in mixed rumen bacteria which may have accounted in part for these overestimates. However, AEPA was not detected in any of the dietary ingredients.

Quantitative information on the proportions of microbial, dietary and endogenous proteins in ruminant duodenal digesta has become essential for estimating the protein requirements of ruminants (Kaufmann, 1977; Roy et al. 1977; Satter \& Roffler, 1977; Journet \& Verité, 1979). Measurement of these components in duodenal digesta is complicated by the fact that many nitrogenous compounds can be both synthesized and degraded in the rumen by the microbial population. Ruminant diets should provide sufficient rumen-degradable protein for optimum microbial protein synthesis, but since this may be insufficient to satisfy the tissue protein requirements of highly productive ruminants, it is necessary to give supplements of dietary protein which are undegraded in the rumen. Such dietary proteins may naturally resist rumen degradation or they may be protected with formaldehyde, tannin, or by heat treatment. Their contribution to the total protein entering at the duodenum is of major importance and is usually assessed by measuring microbial protein and subtracting it from the total, an indirect method often referred to as the difference method. Approaches of this kind require the use of suitable microbial markers for measuring the microbial protein residues. Natural markers used for estimating the proportions of microbial protein in ruminant digesta include RNA (McAllan \& Smith, 1972; 
Ling \& Buttery, 1978), diaminopimelic acid (DAPA) (Hutton et al. 1971) and 2-aminoethyl phosphonic acid (AEPA) which has been used to measure the protozoal component in microbial protein (Hagemeister, 1975; Ling \& Buttery, 1978). Isotopic labels such as ${ }^{35} \mathrm{~S}$, ${ }^{15} \mathrm{~N}$ and ${ }^{32} \mathrm{P}$ have also been used as well as a computer technique using a constrained optimization process (Evans et al. 1975). The methods have been reviewed by Smith (1975) and by Buttery \& Cole (1977), and some of them compared by Smith et al. (1978), Ling \& Buttery (1978), Siddons et al. (1979), Harrison \& McAllan (1980), Mercer et al. (1980) and Theurer (1982). Many of these studies have produced some surprising results which have cast doubt upon the reliability of these techniques, and part at least of the problem may be due to failure to take into account the protozoal and endogenous contributions.

A major criticism of the estimation of undegraded dietary protein by the difference method is that it cannot be considered definitive because there are no means of verification. The most satisfactory way of doing this would be to compare methods under uniform conditions and to measure undegraded dietary- $\mathrm{N}$, bacterial- $\mathrm{N}$ and protozoal- $\mathrm{N}$ simultaneously. Although the endogenous contribution cannot be measured, the sum of these three components should be close to the total non-ammonia-N (NAN) content of the digesta. Apart from those studies (Ling \& Buttery, 1978; El Shazly \& Naga, 1980) in which urea was used as the dietary $\mathrm{N}$ supplement so that most of the $\mathrm{N}$ entering the duodenum would be microbial-N, there has been little attempt to validate these methods because of the difficulty of measuring the dietary- $\mathrm{N}$ contribution. In the present study this has been overcome by using diets supplemented with casein or formaldehyde-treated casein which can be measured directly in digesta from the alkali-labile phosphorus content of the casein (McDonald \& Hall, 1957; Williams \& Smith, 1976). At the same time, the total microbial-N in abomasal digesta was measured using RNA, bacterial-N using DAPA and protozoal-N using AEPA. These results were compared with those obtained by a modification of the amino acid profiling (AAP) method of Evans et al. (1975).

\section{EXPERIMENTAL}

Animals and feeding

Four Friesian steers, which had been weaned at 5-8 weeks on to a normal calf-rearing mixture and hay, were used in these experiments. Operations were performed at 8-15 weeks when the steers were fitted with a rumen cannula (i.d. $38 \mathrm{~mm}$ ) and a simple abomasal cannula (i.d. $11 \mathrm{~mm}$ ) made of Kematal (ICI Plastics Division Ltd, Welwyn Garden City, Herts). The latter was sited in the lateral aspect of the abomasum in the fundus near to the pyloric fundal junction. Periods of at least 3 weeks after the operation, and at least 10 weeks after weaning, were allowed before the experiments were begun.

During the experimental periods the steers were given a basal diet of straw and tapioca (Kingham's Catering Services Ltd, Farnham) containing $4 \cdot 2 \mathrm{~g} \mathrm{~N} / \mathrm{kg}$ dry matter (DM) which was supplemented with either urea, decorticated groundnut meal (DCGM), untreated (UT) casein or formaldehyde-treated (FT) casein to give a total of about $19 \cdot 7 \mathrm{~g} \mathrm{~N} / \mathrm{kg} \mathrm{DM}$ and providing an energy intake (10.5 MJ/kg DM) for a growth rate of about $0.4 \mathrm{~kg} / \mathrm{d}$. Details of these diets are given in Table 1 for steers of 91-113 kg live weight. AEPA and DAPA were not detected in this study and no attempt was made to measure the RNA content of any of the ingredients used. In earlier work Smith \& McAllan (1970) showed that straw and DCGM contained 0.86 and $1.02 \mathrm{mg}$ RNA-N/g DM respectively. Tapioca contains no measurable RNA (A. B. McAllan, personal communication). Urea and casein are unlikely to contain RNA. Each steer was given the concentrate part of the diet in two equal amounts at 09.00 and 17.00 hours along with vitamin and mineral supplements and molasses. The straw was given at 17.00 hours only. There were no feed refusals and water was always available. A pellet of shredded paper impregnated with chromic oxide and $50 \mathrm{ml}$ 
Table 1. Daily amounts $(\mathrm{kg})$ of the main dietary components given to the steers at the time they weighed $91-113 \mathrm{~kg}$; for animals at different live weights these amounts were increased or decreased by about $12 \%$ for each $20 \mathrm{~kg}$ increment in live weight

\begin{tabular}{lccccc}
\hline & Component & \multicolumn{4}{c}{ Diet } \\
\cline { 2 - 5 } & Urea & DCGM & UT casein & FT casein \\
\hline Straw & 1.15 & 1.15 & 1.15 & 1.15 \\
Tapioca & 0.80 & 0.50 & 0.78 & 0.78 \\
Urea & 0.058 & - & - & - \\
Decorticated groundnut meal (DCGM) & - & 0.40 & - & - \\
Untreated (UT) casein* & - & - & - & 0.25 \\
Formaldehyde-treated (FT) casein $\dagger$ & & - & & 0.25 \\
\hline
\end{tabular}

* Lactic acid casein (Casein Industries Ltd, London).

$\uparrow$ Prepared by the low-volume method of Hemsley et al. (1973) at a level of $10 \mathrm{~g}$ formaldehyde $/ \mathrm{kg}$ protein.

of a solution of polyethylene glycol (PEG) $4000(300 \mathrm{~g} / \mathrm{l})$ were introduced into the rumen via the cannula at feeding times to give daily intakes of $3 \cdot 2 \mathrm{~g} \mathrm{Cr}_{2} \mathrm{O}_{3}$ and $30 \mathrm{~g}$ PEG. At least $20 \mathrm{~d}$ were allowed between changing a diet and taking the first samples, each steer receiving each diet in turn according to a $4 \times 4$ Latin-square design.

\section{Sampling of digesta and preparation of microbial samples}

Collections of rumen digesta (about $4 \mathrm{~kg}$ ) were made by gentle suction on days 20 and 28 of each experimental period and were used to prepare isolates of mixed rumen protozoa and bacteria. On day 25 of each period, samples of abomasal digesta (approximately $300 \mathrm{~g}$ ) were taken every $3 \mathrm{~h}$ over a period of $24 \mathrm{~h}$. Total and differential counts of ciliate protozoa were carried out as described by Warner (1962) and, after sub-sampling, the strained digesta were stored at $-20^{\circ}$ until freeze-dried and analysed. Samples of abomasal digesta were obtained by inserting a flexible plastic tube into the cannula and awaiting the gushes of digesta. Enough digesta were usually obtained within $5 \mathrm{~min}$ but occasionally a longer period was necessary. The abomasal samples were thoroughly mixed in an Atomix blender (Measuring and Scientific Instruments Ltd, London) before sub-sampling and storing at $-20^{\circ}$ until freeze-dried and analysed. No attempt was made to separate the digesta into solid and liquid phases at this stage.

\section{Preparation of mixed rumen bacterial isolates}

The bulk samples of rumen digesta were strained through two layers of muslin and about half (approximately $2 \mathrm{~kg}$ ) was used for preparing the bacteria, according to the procedure described by Smith \& McAllan (1974). In cases where the ciliate protozoa count was low, the residues were added to the digesta used to prepare the protozoa to enhance the yield. Microscopic examination was carried out to check that contamination from dietary material was minimal.

\section{Preparation of mixed rumen ciliate protozoal isolates}

The remaining $2 \mathrm{~kg}$ of strained rumen digesta were used for preparing protozoa using a method based on procedures previously described by Ibrahim et al. (1970) and Czerkawski (1976) which were established using steers given similar diets in an earlier investigation (Cockburn, 1982). Protozoa, separated from the rumen digesta, were washed continuously with Hungate buffer $\left(\mathrm{g} / 1 ; \mathrm{NaCl} 5 \cdot 0, \mathrm{CH}_{3} \mathrm{COONa} 1 \cdot 5, \mathrm{~K}_{2} \mathrm{HPO}_{4} 1 \cdot 0, \mathrm{KH}_{2} \mathrm{PO}_{4} 0 \cdot 3\right)$ until the 
supernatant was clear and free of bacteria. Each washing stage was followed by centrifugation at $100 \mathrm{~g}$ for $5 \mathrm{~min}$ and the supernatant was discarded at each stage. The protozoal pellet was made up to $500 \mathrm{ml}$ with formol saline $(40 \mathrm{~g}$ formaldehyde $/ 1$ saline $(9 \mathrm{~g}$ sodium chloride/l)) to kill the cells. A portion of this was then diluted with distilled water, and total and differential counts carried out to determine the yield. Finally, the cells were centrifuged in distilled water to remove traces of buffer salts and immediately freeze-dried. The dried cells were stored at $-20^{\circ}$ to await analysis.

\section{Analytical procedures}

The $\mathrm{Cr}_{2} \mathrm{O}_{3}$ and PEG contents of the abomasal digesta were determined as described by Williams \& Smith (1974) and Smith \& McAllan (1971) respectively. DM content was estimated after heating at $105^{\circ}$ for $24 \mathrm{~h}$. Total-N was estimated as described by Smith \& McAllan (1970) and ammonia- $\mathrm{N}$ as described by Merry (1980). The methods used for determining casein-P were those of McDonald \& Hall (1957) using the modifications described by Williams \& Smith (1976). RNA was estimated by the method of McAllan \& Smith (1969).

AEPA analysis. The method used was a modification of the procedures of Czerkawski (1974) and El Shazly et al. (1975) in which hydrolysis of the samples for $48 \mathrm{~h}$ at $110^{\circ}$ in $6 \mathrm{M}-\mathrm{HCl}$ is followed by the separation of AEPA from inorganic phosphate using ion exchange chromatography on columns $(100 \times 17 \mathrm{~mm})$ of Amberlite CG $400(\mathrm{Cl})$ resin (BDH type 1, 100-200 mesh). The procedure for the hydrolysis of the C-P bond of AEPA was similar to that of Kirkpatrick \& Bishop (1971). The $50 \mathrm{ml}$ of eluant containing AEPA was concentrated to $1.0 \mathrm{ml}$ by rotary evaporation, transferred to phosphate-free Pyrex test-tubes $(180 \times 15 \mathrm{~mm})$ containing $3 \mathrm{ml}$ acid mixture (to make up the acid mixture, place $98 \mathrm{ml} \mathrm{H}_{2} \mathrm{SO}_{4}$ in $230 \mathrm{ml}$ deionized water, cool, add $1200 \mathrm{ml} \mathrm{HNO}_{3}$ and $120 \mathrm{ml} \mathrm{HClO}_{4}$ and adjust to $1800 \mathrm{ml}$ with deionized water) and then hydrolysed for $2 \mathrm{~h}$ at $225^{\circ}$ in an aluminium block, electric tube heater with temperature control unit (Model 451; Scienco-Western Ltd, Toft, Cambridge). Hydrolysis at this temperature gave reproducible final volumes $(0.2 \mathrm{ml})$ of $\mathrm{H}_{2} \mathrm{SO}_{4}$. After dilution with deionized water to $2.5 \mathrm{ml}$ any residual material was dissolved by incubating at $40^{\circ}$. The inorganic phosphate in the samples was determined using an autoanalyser procedure based on the formation of phosphomolybdic acid and its subsequent reduction by 1-amino-2-naphthol-4-sulphonic acid to give a blue colour which was measured at $660 \mathrm{~nm}$ (Technicon Instruments Corporation, 1967). This procedure was found (Cockburn, 1982), to give higher recoveries of inorganic phosphate from amino-phosphonate standards than the procedures described by Czerkawski (1974) and El Shazly et al. (1975). The same hydrolysis and phosphate assay procedure was used for determining total-P (TP) in freeze-dried samples of rumen bacteria, protozoa and abomasal digesta.

Attempts were also made to determine AEPA by automatic amino acid analysis (Hagemeister, 1975; Ling \& Buttery, 1978) but this approach was abandoned when it was found that AEPA was eluted as two incompletely resolved peaks (Cockburn \& Williams, 1982). Difficulties associated with the low colour yield of AEPA with ninhydrin meant that quantification of the AEPA peaks using this procedure was unreliable (Cockburn, 1982).

Amino acid and hexosamine analysis. Most amino acids were estimated after hydrolysing the samples with $6 \mathrm{M}-\mathrm{HCl}$ at $110^{\circ}$ for $24 \mathrm{~h}$ by the method of Spackman et al. (1958), but cystine and methionine were determined by the method of Mason et al. (1980). The analyses were carried out using a Biotronik LC 2000 automatic analyser (Biotronik, Frankfurt). With small modifications to the $\mathrm{pH}$ and sodium ion concentration of the eluting buffer and by extending the analysis time, it was possible to resolve all the common amino acids as well as DAPA and the hexosamines. The column $(350 \times 6 \mathrm{~mm})$ containing Durrum DC6A (resin bed height $250 \mathrm{~mm}$ ) was eluted sequentially with five buffers (buffer $1: \mathrm{pH} 3 \cdot 29,0 \cdot 16 \mathrm{M}-\mathrm{Na}^{+}$, 8 min; buffer 2: $\mathrm{pH} 4 \cdot 05,0.16 \mathrm{M}-\mathrm{Na}^{+}, 17 \mathrm{~min}$; buffer 3: $\mathrm{pH} 4 \cdot 35,0 \cdot 16 \mathrm{M}-\mathrm{Na}^{+}, 22 \mathrm{~min}$; buffer 
4: $\mathrm{pH} 4.85,1.6 \mathrm{M}-\mathrm{Na}^{+}, 60 \mathrm{~min}$; buffer 5: $\left.\mathrm{pH} \mathrm{2.30,1 \cdot 1} \mathrm{M}-\mathrm{Na}^{+}, 15 \mathrm{~min}\right)$. The buffer flow rate through the column was $35 \mathrm{ml} / \mathrm{h}$ and column temperature was $49^{\circ}$ for the first $15 \mathrm{~min}$ of analysis and $61^{\circ}$ for the remainder. The total analysis time, including regeneration and equilibrium, was $187 \mathrm{~min}$. Estimates of DAPA by this procedure were in close agreement with those carried out by the procedure of Smith et al. (1978).

The amino acid profiling procedure. The procedure described by Evans et al. (1975) and Offer et al. (1978) was modified to obtain estimates of protozoa as well as bacteria in abomasal or duodenal digesta. The computer procedure was an iterative optimizing process (NAG Library Procedure, EO4 CAA) which assumes that the sum of the endogenous, protozoal, bacterial and dietary AAPs is equal to the digesta profile. The AAP for bovine pepsinogen (calculated from Chow \& Kassel, 1968) was used to represent the endogenous secretion at the abomasum (Table 7, p. 121) since it is not possible to measure the endogenous component directly. Amino acid analyses were carried out on all the proteincontaining components of the diet (Table 7) as well as on rumen protozoa and bacteria (Table 4, p. 118) and abomasal digesta (Table 6, p. 120) for each period of the experiment. The amounts of dietary components flowing to the abomasum or duodenum were constrained so that they did not exceed their intake.

Modifications and evaluation of amino acid profiling procedure. As well as modifying the procedure to include a profile for protozoa, the profiles for each component were extended, where appropriate, to include the amino acids cystine, DAPA and AEPA, and the hexosamines glucosamine and galactosamine, and a comparison using profiles consisting of sixteen and twenty-one amino acids and hexosamines was carried out to see if there was any marked effect on the computed proportions of each component found at the abomasum (Table 8, p. 122).

The validity of the modified procedure was tested using five different mixtures of known composition, prepared from samples of straw, DCGM, UT casein, porcine pepsin and rumen protozoa and bacteria prepared from a steer given the DCGM diet (Table 1). The amino acid composition of these components is given in Table 7. The proportion of each component in the mixture was determined using the modified profiling procedure and the results compared with the known composition of each of the mixtures (Table 9, p. 123). The mixtures used were of increasing complexity, the most complex being mixture 5 which contained straw, pepsin, bacteria and protozoa in proportions similar to those that might be expected in abomasal digesta. Neither DCGM nor UT casein was added to this mixture since it was assumed that the abomasal digesta of animals given these supplements would contain very little of these highly degradable proteins.

\section{Quantitative estimation of constituents flowing into the duodenum}

Amounts of digesta constituents (total N (TN), ammonia N, amino acid-N, AEPA, DAPA, RNA and casein-N) and the absolute amounts of microbial-, dietary, and endogenous-N (estimated from the modified AAP procedure) leaving the abomasum in $24 \mathrm{~h}$ were determined from their ratios to the non-absorbed markers $P E G$ and $\mathrm{Cr}_{2} \mathrm{O}_{3}$ in the appropriate digesta samples and the $24 \mathrm{~h}$ intakes of these markers (McAllan \& Smith, 1983). Where appropriate, these constituents were also determined in the washed, mixed protozoal and mixed bacterial cells prepared from the corresponding rumen digesta samples. The proportion of NAN in the abomasal digesta, which was derived from the rumen ciliate protozoa, rumen bacteria and total microbial cells, was found by substituting the appropriate results in:

$$
\frac{\mathrm{TN} \text { (microbial cells) }}{\text { Marker-N (microbial cells) }} \times \frac{\text { Marker-N (abomasal digesta) }}{\text { NAN (abomasal digesta) }} .
$$


Casein- $\mathrm{N}$ as a proportion of abomasal NAN was estimated as:

$$
\text { Casein-P (abomasal digesta) } \times \frac{N / P \text { (casein) }}{\text { NAN (abomasal digesta) }} .
$$

\section{Statistical analysis}

Statistical analysis of the data followed the standard analysis of variance for a $4 \times 4$ Latin-square (Cochran \& Cox, 1962).

\section{RESULTS}

The effect of diet on the rumen protozoal concentrations

The total and differential protozoal counts are given in Table 2, and the variations between animals for most of the diets were greater than the variations due to the diets themselves. Higher numbers of dividing protozoa were observed in the rumen of steers given the ureaand FT casein-supplemented diets than when UT casein and DCGM were given. Total protozoal numbers/g DM were also determined in the final washed preparations just before freeze-drying. The samples and the results given in Table 2 show that there are some marked differences, particularly for the protozoal DM isolated from the steers given supplements of UT casein and urea. The results of the differential counts show that the small entodinium species were the predominant group throughout the experiment. The holotrich protozoa were not present in large numbers and were completely absent from two of the animals. Low numbers of large ophryoscolecids were present in most collections, but these only exceeded $10 \%$ of the population on one occasion.

\section{The effect of diet on the composition of protozoa and bacteria}

The effect of diet on the AEPA-N:TN and TN content of the protozoa was not significant (Table 3). However, the total $P$ content of the protozoa was significantly $(P<0.05)$ greater in steers given the UT casein diet. The amino acid and hexosamine composition of the ciliate protozoa is given in Table 4. No significant differences due to diet were apparent, with the exception of arginine $(P<0.05)$ which was highest when the urea diet was given. The DAPA content of the protozoa was always very small and in many cases not measurable. The amino acid composition of the protozoa agreed closely with literature values except for isoleucine and valine which were 15 and $20 \%$ lower respectively in the present study.

The TN, TP composition and values of DAPA-N:TN, RNA-N:TN and AEPA-N:TN of the rumen bacterial DM are given in Table 3. The amino acid and hexosamine composition of the bacteria is given in Table 4. No significant effects due to dietary differences were apparent for the TN, DAPA-N:TN, RNA-N:N and AEPA-N:N of the bacteria. AEPA, at about one-third of the concentrations found in ciliate protozoa, was detected in all the bacterial preparations (32) in this study. Diet had little effect on the amino acid and hexosamine composition of the bacteria, with the exception of histidine which was significantly $(P<0.05)$ higher for bacteria isolated from steers given the FT casein diet than from steers given the DCGM diets. Bacteria isolated from steers given the UT casein diet also contained less histidine than bacteria from steers given FT casein, but the difference was not significant. The amino acid composition of the bacteria prepared in this study was similar to values reported by previous workers except for valine, isoleucine, tyrosine and lysine which were 16-19\% lower in the present study.

\section{Flow of various constituents at the abomasum}

Quantities of digesta constituents entering the abomasum in $24 \mathrm{~h}$ were estimated as described earlier. Mean (with SE) values based on PEG for NAN flow $(\mathrm{g} / 24 \mathrm{~h})$ for diets supplemented with either urea, DCGM, UT casein or FT casein were $38 \cdot 1(4 \cdot 7), 50 \cdot 3(6 \cdot 9)$, 


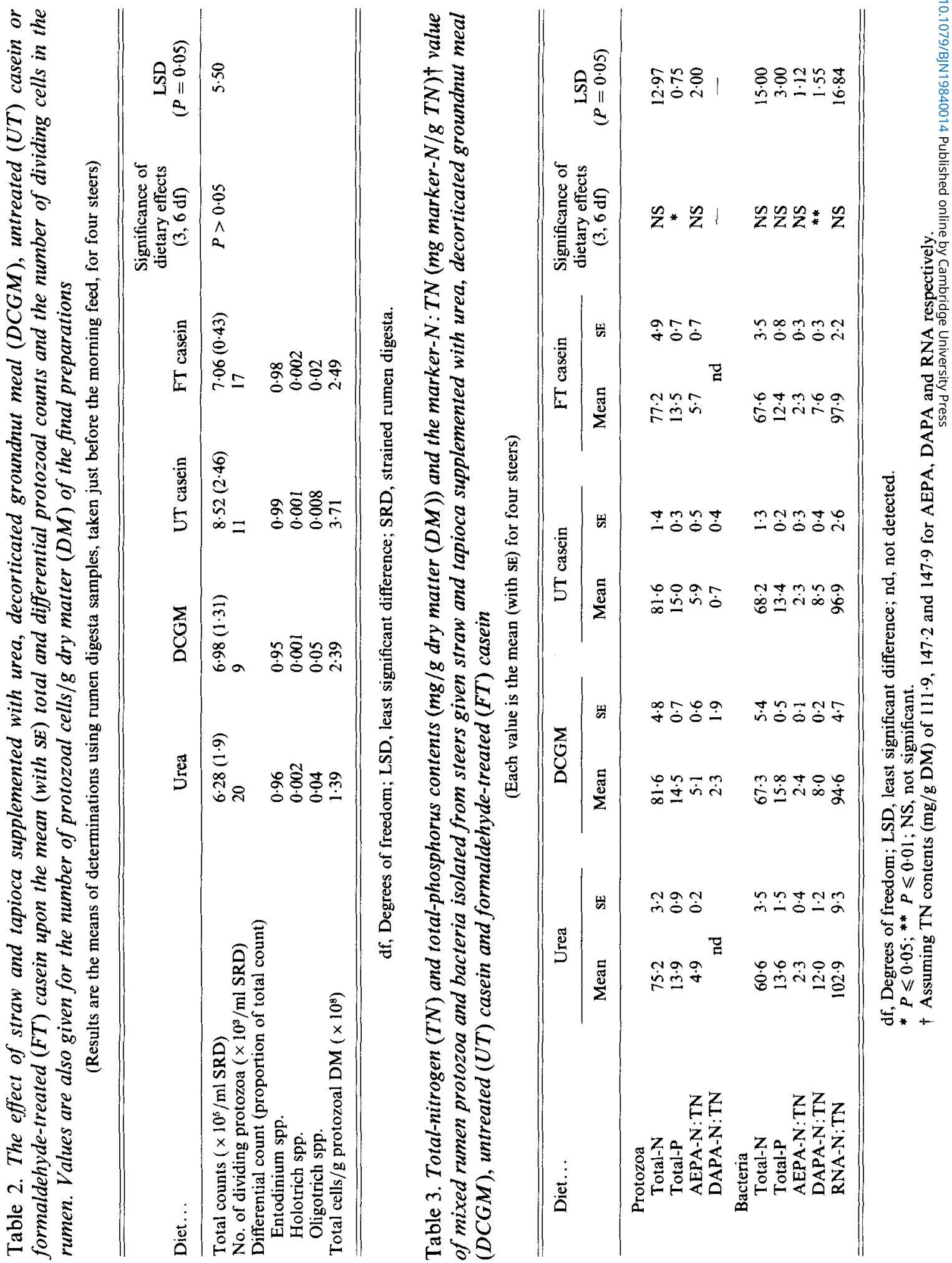




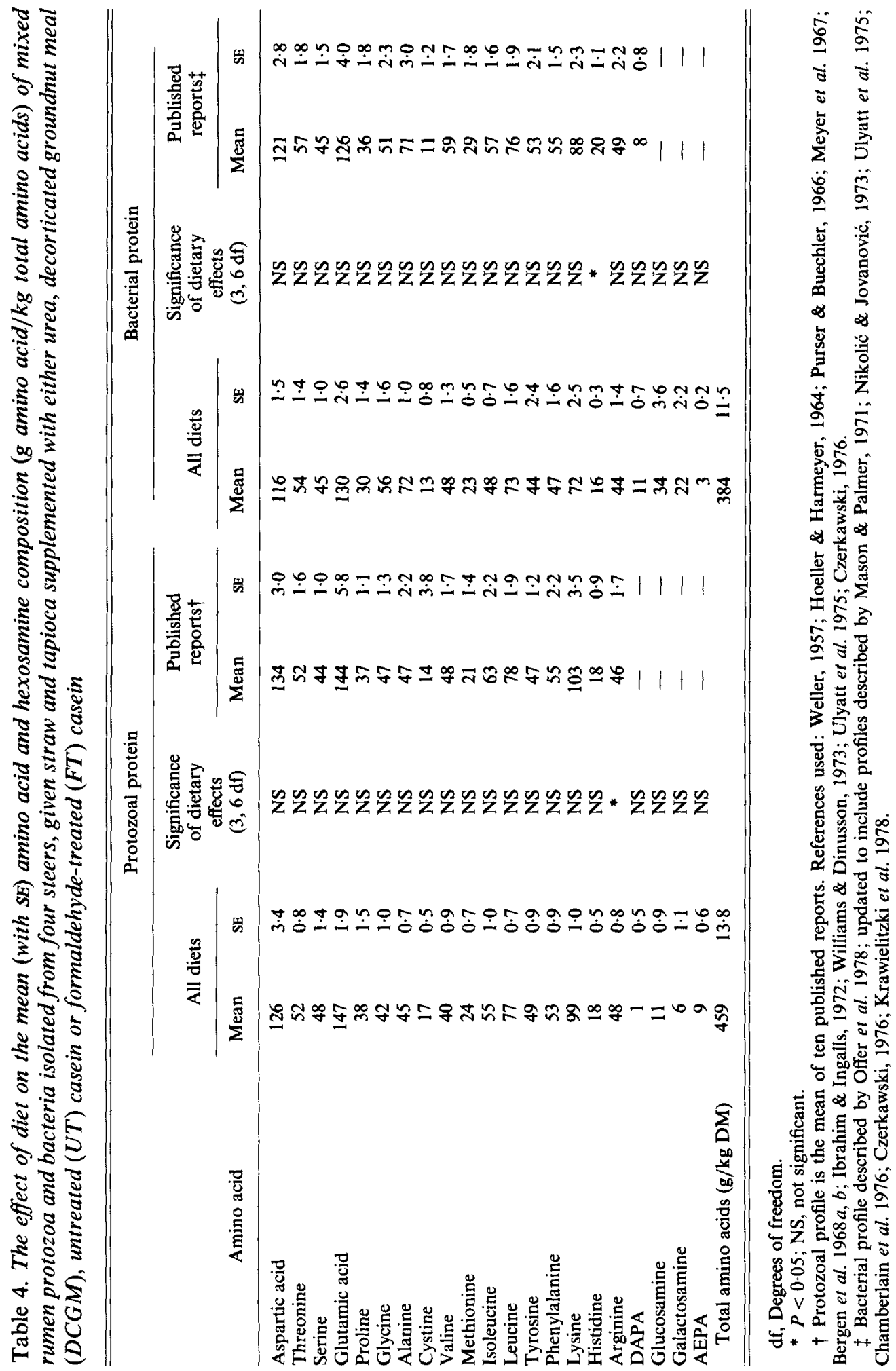




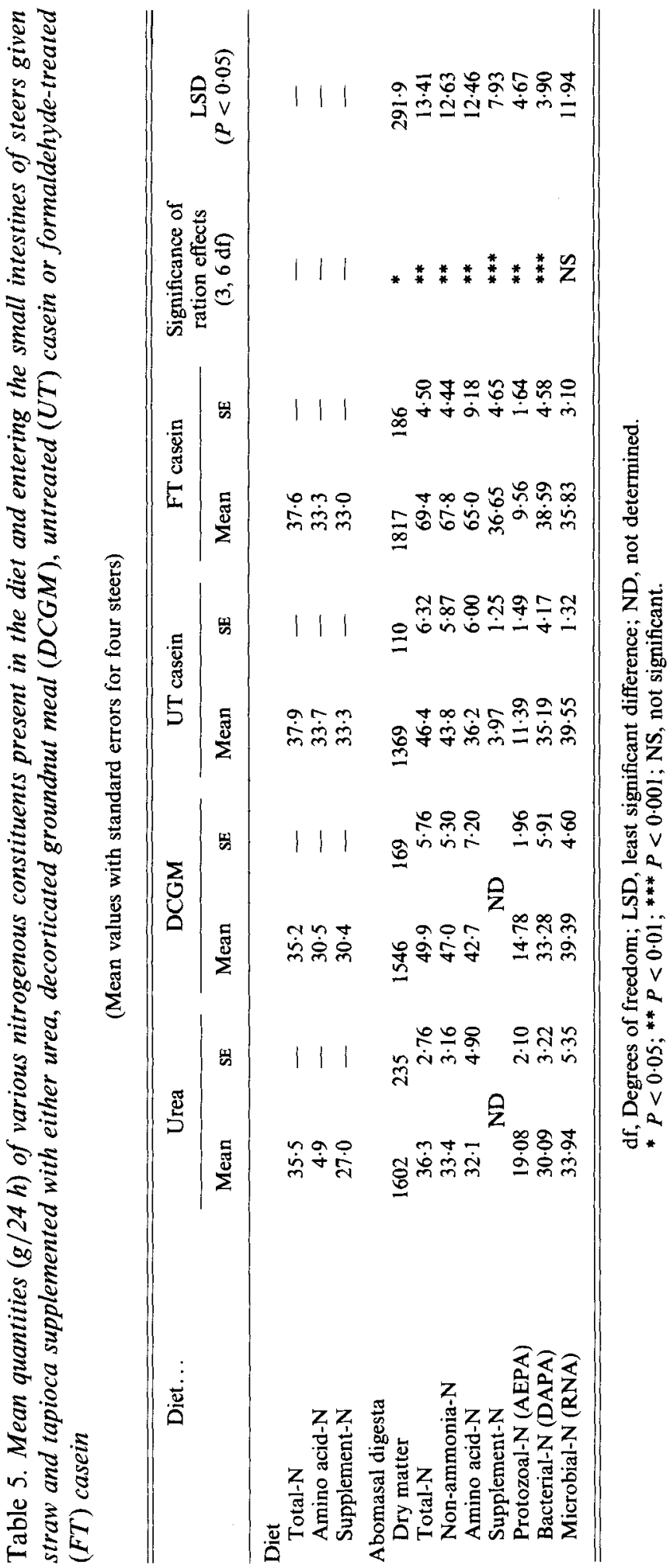




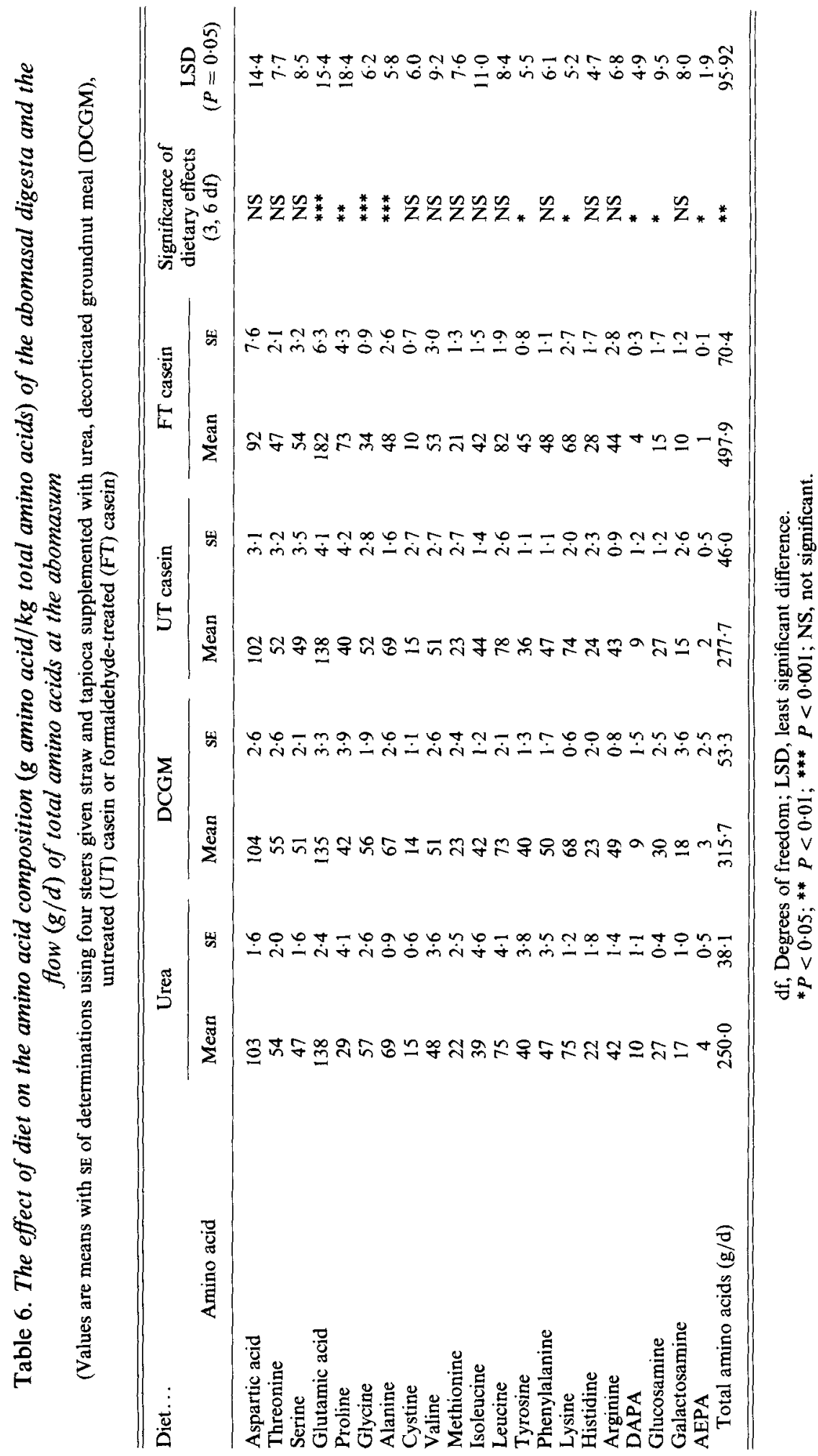


Table 7. The amino acid composition of the diets given to the steers and of the bovine pepsinogen and porcine pepsin used in the amino acid profiling procedure

(Values are expressed as $\mathrm{g}$ amino acid $/ \mathrm{kg}$ amino acids)

\begin{tabular}{|c|c|c|c|c|c|c|}
\hline Amino acid & Straw & DCGM & UT casein & FT casein & $\begin{array}{c}\text { Bovine } \\
\text { pepsinogen* }\end{array}$ & $\begin{array}{c}\text { Porcine } \\
\text { pepsin }\end{array}$ \\
\hline Aspartic acid & $106 \cdot 6$ & $108 \cdot 8$ & $75 \cdot 1$ & 74.8 & 119 & 133 \\
\hline Threonine & 53.9 & 25.9 & 38.5 & $40 \cdot 0$ & 71 & 70 \\
\hline Serine & $64 \cdot 1$ & $48 \cdot 0$ & $50 \cdot 2$ & $54 \cdot 5$ & 116 & 101 \\
\hline Glutamic acid & $131 \cdot 5$ & $192 \cdot 4$ & 203.8 & $209 \cdot 5$ & 105 & 104 \\
\hline Proline & $45 \cdot 6$ & $49 \cdot 0$ & $116 \cdot 6$ & $110 \cdot 3$ & 39 & 49 \\
\hline Glycine & $70 \cdot 1$ & $70 \cdot 8$ & $20 \cdot 0$ & $19 \cdot 5$ & 58 & 66 \\
\hline Alanine & $76 \cdot 9$ & 55.5 & $28 \cdot 7$ & $30 \cdot 6$ & 31 & 50 \\
\hline Cystine & $35 \cdot 4$ & $19 \cdot 3$ & $6 \cdot 3$ & 7.7 & 32 & 17 \\
\hline Valine & $44 \cdot 8$ & $42 \cdot 4$ & $50 \cdot 2$ & 53.4 & 65 & 58 \\
\hline Methionine & $11 \cdot 3$ & 13.6 & $29 \cdot 2$ & $30 \cdot 2$ & 13 & 17 \\
\hline Isoleucine & 36.9 & $30 \cdot 4$ & $38 \cdot 3$ & $42 \cdot 9$ & 92 & 70 \\
\hline Leucine & $80 \cdot 6$ & $70 \cdot 8$ & $94 \cdot 1$ & $89 \cdot 5$ & 73 & 94 \\
\hline Tyrosine & $28 \cdot 3$ & $39 \cdot 4$ & 57.5 & 44.9 & 71 & 86 \\
\hline Phenylalanine & $38 \cdot 4$ & 53.7 & $51 \cdot 5$ & 50.8 & 55 & 68 \\
\hline Lysine & $47 \cdot 5$ & 33.9 & $73 \cdot 2$ & $72 \cdot 1$ & 26 & 4 \\
\hline Histidine & $15 \cdot 4$ & 25.5 & $28 \cdot 6$ & $31 \cdot 0$ & 7 & 4 \\
\hline Arginine & $44 \cdot 8$ & $120 \cdot 3$ & $38 \cdot 1$ & $38 \cdot 3$ & 23 & 9 \\
\hline DAPA & Nil & Nil & Nil & Nil & ND & ND \\
\hline Glucosamine & $51 \cdot 6$ & Nil & Nil & Nil & ND & ND \\
\hline Galactosamine & $16 \cdot 2$ & $\mathrm{Nil}$ & Nil & Nil & ND & ND \\
\hline AEPA & $\mathrm{Nil}$ & Nil & $\mathrm{Nil}$ & Nil & ND & $\mathrm{Nil}$ \\
\hline
\end{tabular}

ND, not determined.

* Chow \& Kassel (1968).

$42 \cdot 1(4 \cdot 8)$ and $69 \cdot 0(7 \cdot 6)$ respectively. Corresponding values based on $\mathrm{Cr}_{2} \mathrm{O}_{3}$ were $28 \cdot 8(1 \cdot 6)$, $43.7(5.0), 45 \cdot 5(6.9)$ and $66.6(6.4)$. The differences between markers were not significant and it was considered that sampling was not markedly biased towards liquid or solid fractions of the digesta. It was considered reasonable, for the purposes of this study, to assume that the true values would lie somewhere between those found for each marker. Therefore mean values based on PEG and $\mathrm{Cr}_{2} \mathrm{O}_{3}$ are given in Table 5. The lower daily flow of DM when UT casein was given was found to be just significant $(P<0.05)$. More TN, NAN and amino acid-N (AAN) entered the abomasum when FT casein was given. When urea was given these quantities were much lower, markedly so for TN and NAN. The large increases in the flows of AAN, NAN and TN when FT rather than UT casein was given were undoubtedly due to the higher flow of casein- $N$ at the abomasum. The difference in the flow of casein- $\mathrm{N}$ at the abomasum when these two supplements were given was highly significant $(P<0.001)$ and clearly indicates the effect of protecting the casein supplement with formaldehyde. Direct estimates of the contribution of urea and DCGM to the abomasal NAN were not possible. When the urea diet was given, lower $(P<0.01)$ TP contents were found in the abomasal digesta. The mean (with SE) values obtained when urea, DCGM, UT casein and FT casein were given, were 6.3 (0.7), 10.3 (0.9), 9.9 (0.9) and 8.6 (0.9) $\mathrm{mg} \mathrm{P} / \mathrm{g}$ DM respectively.

The mean (with SE) daily flows of total amino acids at the abomasum and the amino acid composition of the abomasal digesta are given in Table 6. Glutamic acid was much higher, and glycine and alanine much lower, for the FT casein diet than when the urea, DCGM and UT casein diets were given. Other differences which reached signficance when the FT 


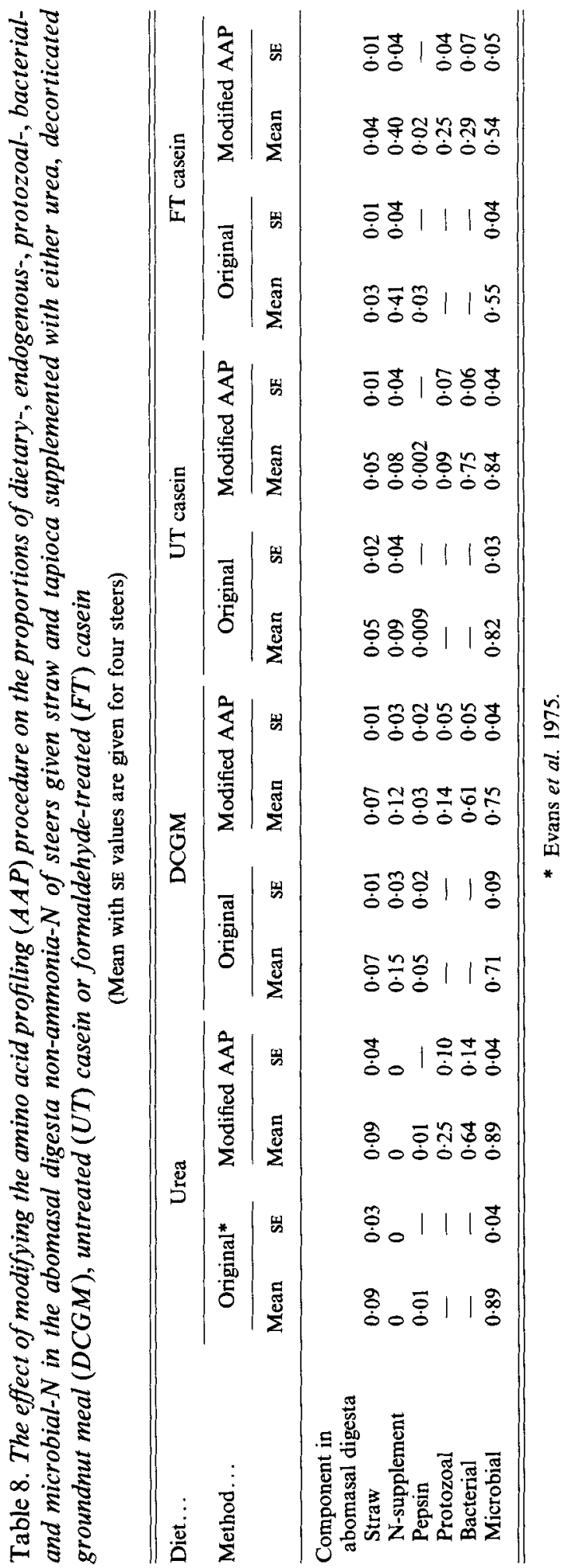


Table 9. Evaluation of the modified amino acid profiling procedure using mixtures of known composition

(Values are proportions of total amino acids contributed by each component)

\begin{tabular}{|c|c|c|c|c|c|}
\hline \multirow[b]{2}{*}{ Mixture } & \multicolumn{5}{|c|}{ Component in prepared mixture } \\
\hline & Straw & Pepsin & N-supplement & Protozoa & Bacteria \\
\hline 1 Actual & 0 & 0 & $0.12^{*}$ & $0 \cdot 14$ & 0.74 \\
\hline Computed & 0 & 0 & $0 \cdot 14^{*}$ & 0.19 & 0.64 \\
\hline 2 Actual & 0 & 0 & $0 \cdot 21 \dagger$ & $0 \cdot 16$ & 0.63 \\
\hline Computed & 0 & 0 & $0.25 \dagger$ & $0 \cdot 15$ & 0.60 \\
\hline 3 Actual & 0 & 0 & $0.38 \dagger$ & $0 \cdot 10$ & 0.52 \\
\hline Computed & 0 & 0 & $0.38 \dagger$ & 0.11 & 0.50 \\
\hline 4 Actual & 0 & 0 & $0.40 \dagger$ & 0.20 & $0 \cdot 40$ \\
\hline Computed & 0 & 0 & $0.37 \dagger$ & $0 \cdot 36$ & $0 \cdot 28$ \\
\hline 5 Actual & $0 \cdot 10$ & 0.01 & 0 & 0.21 & 0.65 \\
\hline Computed & $0 \cdot 10$ & 0 & 0 & 0.24 & 0.66 \\
\hline
\end{tabular}

* Decorticated groundnut meal.

$\dagger$ Untreated casein.

casein diet was given were found for proline $(P<0.01)$, tyrosine, lysine and glucosamine $(P<0.05)$.

\section{Evaluation of the modified amino acid profiling procedure}

The amino acid compositions of the dietary components and porcine pepsin used in this study are given in Table 7. Amino acids were absent from urea and present in only trace amounts in tapioca. With the exception of lysine and alanine, the amino acid profiles of rumen protozoa and bacteria were similar, and it was considered that the inclusion of values of those amino acids (AEPA and DAPA) and hexosamines, for which there are marked differences, might improve their differentiation. Results comparing this modified procedure with the original (Evans et al. 1975) are given in Table 8. Whatever the dietary supplement there was little effect on the proportions of microbial, dietary and endogenous components found at the abomasum as a result of adding more amino acids or hexosamines to the profiles. However, the inclusion of a profile for protozoa resulted in the differentiation between bacterial- and protozoal- $\mathrm{N}$ in the digesta.

When the DCGM and UT casein diets were given, the total microbial component determined using the modified procedure was slightly higher than when the original method was used (Table 8), suggesting that the use of the bacterial profile alone to estimate the microbial-N might possibly have led to its underestimation. However, when the urea and FT casein diets were given, both of which resulted in the highest proportions of protozoal-N in abomasal digesta, the microbial components estimated by both methods were almost identical. The modified procedure was therefore used for subsequent work and validated by determining the different components in synthetic mixtures of known composition. A comparison of these results with the known proportions of amino acids is given in Table 9 and shows close agreement for mixtures 1,2,3 and 5, where the actual and predicted amino acid contents were similar. Agreement was less good for mixture 4, in which the values determined by amino acid analysis were lower than those predicted from amino acid analysis of the components. This result illustrates the importance of the accuracy of amino acid analysis in the AAP method. Although the computed levels in mixture 4 showed markedly higher protozoal $(+0 \cdot 16)$ and lower bacterial $(-0 \cdot 12)$ components than were actually 
Table 10. The proportion of microbial-, bacterial- and protozoal-and dietary- $N$ in abomasal $N A N$ of steers given straw and tapioca supplemented with either urea, decorticated groundnut meal (DCGM), untreated (UT) casein or formaldehyde-treated $(F T)$ casein, using the markers $R N A$, diaminopimelic acid $(D A P A), 2$-aminoethyl phosphonic acid $(A E P A)$ and casein-P respectively

(The mean values obtained using these markers are compared with values determined using amino acid profiling)

\begin{tabular}{|c|c|c|c|c|c|c|c|c|}
\hline \multirow[b]{2}{*}{ Component } & \multicolumn{4}{|c|}{ Markers } & \multicolumn{4}{|c|}{ Amino acid profiling } \\
\hline & Urea & DCGM & $\begin{array}{c}\mathrm{UT} \\
\text { casein }\end{array}$ & $\begin{array}{c}\text { FT } \\
\text { casein }\end{array}$ & Urea & DCGM & $\begin{array}{c}\text { UT } \\
\text { casein }\end{array}$ & $\begin{array}{c}\mathrm{FT} \\
\text { casein }\end{array}$ \\
\hline Microbial (RNA) & 0.98 & 0.85 & 0.92 & 0.53 & 0.89 & 0.75 & 0.84 & 0.54 \\
\hline Bacterial (DAPA) & 0.88 & $0 \cdot 70$ & 0.81 & 0.57 & 0.64 & 0.61 & 0.75 & 0.29 \\
\hline Protozoal (AEPA) & $0 \cdot 56$ & $0 \cdot 32$ & 0.27 & $0 \cdot 16$ & $0 \cdot 25$ & $0 \cdot 14$ & 0.09 & 0.25 \\
\hline Dietary & ND & $0 \cdot 12^{*}$ & 0.09 & 0.51 & 0.0 & $0 \cdot 12$ & 0.08 & 0.40 \\
\hline Total (DAPA + AEPA + dietary) & $1 \cdot 44$ & $1 \cdot 14$ & $1 \cdot 17$ & $1 \cdot 24$ & 0.89 & 0.87 & 0.92 & 0.94 \\
\hline
\end{tabular}

ND, not determined.

* Assumed from profiling value.

present, the proportions of the total microbial and casein components determined were close to the predicted values. On the basis of these results, the modifications made to the AAP procedure were considered to be valid.

\section{Comparison of different methods of estimating the proportions of microbial- $N$ and} dietary- $N$ components in abomasal $N A N$

The results are given in Table 10 . The dietary- $N$ contribution, when urea was given, was assumed to be zero. When DCGM was given, its contribution could not be determined experimentally and therefore the value of 0.12 obtained by the AAP method was used. This was considered to be a reasonable assumption, since DCGM is only slightly less degradable than casein (Agricultural Research Council, 1980). The AAP method was constrained so that the components of the abomasal NAN did not exceed 1.00.

\section{DISCUSSION}

The effect of diet on the protozoal populations was small, probably because the straw and tapioca had a greater influence than the $\mathrm{N}$ supplements in this study. The consistently high proportion of entodinium species in the population could be attributed to the high level of starch, mainly in the form of tapioca, in the diets (Abou Akkada \& Howard, 1960). Holotrichs, on the other hand, prefer to metabolize sugars (Hungate, 1966) and these were probably in short supply in the present study because the roughage in the diet (straw) was lacking in this constituent. Greater variations in protozoal numbers were found between animals than between diets, a finding which has also been reported by Valdez et al. (1977), Jouany (1978) and Wakita \& Hoshino (1979).

Diet also had little effect on the composition of the protozoa and bacteria, with the exception of the TP content of the protozoa when the FT casein and urea diets were given. The range of dietary $P$ in the present study was not very great, but if one assumes that the $P$ in FT casein was not available for microbial synthesis, then this may explain why the levels of TP in protozoa associated with this diet were lower. The protozoal TP concentrations in the present study were similar to those observed by Nour et al. (1979) 
and by Czerkawski (1976) for polysaccharide-free material. However, the value obtained by Czerkawski (1974) for protozoa containing polysaccharide was much lower, and Abou Akkada et al. (1968) reported values that were three to four times higher than in the present study. Low levels of DAPA, presumably due to bacterial contamination and/or engulfment or to bacteria living commensally within the protozoal cells, were found in some of the protozoal isolates. The DAPA content of the bacteria isolated from steers given the urea diet was markedly higher and the $\mathrm{N}$ content was slightly lower, which resulted in a significantly $(P<0.01)$ higher DAPA-N:TN value. This difference may have been due to the presence of different species of bacteria of different composition (Synge, 1953; Purser \& Buechler, 1966) or it may reflect differences in the DM content of the bacterial cells.

The amino acid composition of rumen protozoa and bacteria in this study agreed with published values (Table 4), with the exceptions of valine and isoleucine in protozoa and of valine, isoleucine, tyrosine and lysine in bacteria. These differences are probably analytical and may be due to the improvement achieved in the resolution of these amino acids from DAPA and the hexosamines in the present study.

The composition of the abomasal digesta was more variable than the composition of the microbial cells and was clearly affected by the use of different $\mathrm{N}$ supplements in the diet. Particularly evident were reductions in the microbial constituents (AEPA, DAPA and RNA) when FT casein rather than UT casein was given to the steers, probably due to the inadequate supply of fermentable $\mathrm{N}$ for maximum microbial synthesis in the rumen (Williams \& Smith, 1976).

Diet usually has little effect on the amino acid composition of abomasal digesta, especially with proteins of high degradability, since the opposing rumen processes of degradation of dietary proteins and synthesis of microbial proteins tend to result in a supply of protein of fairly consistent amino acid composition due to the high proportion of microbial protein (Smith, 1983). This was confirmed in the present study for the urea, DCGM and UT casein diets. Exceptions, for the DCGM diet, were the slightly higher (but not significant) arginine content and the lower lysine content, which was just significant $(P<0.05)$. These differences probably reflect the low lysine and high arginine contents of DCGM (Williams \& Smith, 1974). On the other hand, the low degradability of the FT casein supplement produced some marked changes in amino acid composition at the abomasum (Tables 5 and 6). The presence of higher levels of undegraded dietary casein and smaller amounts of microbial proteins in the digesta increased the levels of serine, glutamic acid, valine, leucine and histidine, and decreased the levels of glycine, alanine and cystine. Similar effects on the amino acid composition of duodenal digesta were reported by Williams \& Smith (1976) for cattle given UT and FT casein supplements. The amino acid content of the straw, DCGM, UT casein and FT casein (Table 7) was in agreement with previous analyses for similar materials used by Williams (1974).

Modifications of the AAP procedure to include the AAP for rumen protozoa, as well as for rumen bacteria, enabled these two components to be quantified in the abomasal digesta. This was an improvement on the original method, where bacterial profiles alone were used to define the total microbial component in the digesta. Little advantage accrued from including additional amino acids in the profiles, although this may be more useful when dietary and microbial profiles are very similar, for example, grass silage and dried grass (Siddons et al. 1979), and differentiation between the various components is difficult.

The AAP procedure is very sensitive to errors in amino acid analysis but it has been shown in the present study that it can provide reliable values for synthetic mixtures of known composition. However, it should be possible to reduce errors from this source by using profiles obtained for micro-organisms isolated from animals used in the actual study. As is the case with other microbial markers, it is desirable to know the value of the ratio of 
the chosen component or marker to $\mathrm{N}$ in the micro-organisms which contribute to the abomasal digesta. In some studies using the AAP procedure (Evans et al. 1975; Offer et al. 1978), values obtained in different experiments under different conditions were used. This is not ideal, and indeed, in later studies from the same laboratory (Tas et al. 1981), the AAP of microbial protein isolated from the sheep under investigation was used. The concentrations of some of the amino acids, aspartic acid, leucine, histidine and lysine, present in the microbial protein used by Tas et al. (1981) were quite different from their concentrations in the bacterial protein profile used by Evans et al. (1975) and Offer et al. (1978). In the present study, significant differences were found in the arginine values for protozoal DM when urea was given, and in the histidine values of bacterial DM when FT casein was given, emphasizing the importance of isolating microbial samples for each diet that is used. Another criticism of the AAP procedure is that it assumes that each dietary component behaves as a single entity and that the amino acid composition of the dietary components bypassing the rumen resembles that of the original materials. However, recent studies (MacGregor et al. 1978; Mathers et al. 1979) suggest that this assumption may not be valid because of the different structural configurations and solubilities of feed proteins.

The use of the AAP of bovine pepsinogen for the endogenous component can also be criticized on the grounds that pepsin accounts for only small parts of the $\mathrm{N}$ in abomasal secretions (Harrop, 1974). In a recent study, using another modified AAP method, Cottle \& Nolan (1982) suggested that the endogenous profile was better represented by albumin than pepsinogen. The endogenous contribution to abomasal digesta, determined by AAP, is quite small, $0 \cdot 1-1.6 \mathrm{~g} \mathrm{~N} / \mathrm{d}$. This is close to estimates of $1 \cdot 1-2 \cdot 2 \mathrm{~g} \mathrm{~N} / \mathrm{d}$ and $3 \mathrm{~g} \mathrm{~N} / \mathrm{d}$ made for the size of the animal used in the present study, from studies of endogenous secretions in ruminants, by Ørskov \& MacLeod (1982) and Harrop (1974) respectively.

The proportions of dietary-N to NAN at the abomasum, determined by AAP, were consistent with the nature of the diets used. For example, low levels of straw would be expected since its $\mathrm{N}$ contribution would be small. The levels of DCGM and UT casein would also be expected to be small since these proteins are highly degradable in the rumen. On the other hand the low rumen degradability of FT casein should result in increased levels of this dietary component at the rumen.

Evans et al. (1975) evaluated the original AAP procedure by using data from published results of other workers, and agreement with estimates of microbial protein using other markers, such as DAPA and RNA, were not always good. The present study has validated the AAP method with synthetic mixtures containing known amounts of dietary, microbial and endogenous proteins. It is evident from Table 10, since the sum of bacterial- (or microbial-), protozoal- and dietary- $\mathrm{N}$ is greater than unity, that the four marker procedures used in this study have overestimated the proportions of microbial- and dietary- $\mathrm{N}$ in the abomasal digesta. This is not surprising since all of the procedures used have limitations. With the exception of the investigations of Ling \& Buttery (1978) and E1 Shazly \& Naga (1980), most other studies, in which several microbial markers have been compared under the same conditions, have been confounded by lack of information on the dietary contribution to the digesta. In the present study, an attempt was made to overcome this criticism by using UT casein or FT casein.

Direct measurement of casein entering the abomasum indicated that giving FT rather than UT casein led to much greater amounts of dietary casein escaping degradation in the rumen $(111 \%$ compared to $12 \%)$. The results obtained when UT casein was given are in good agreement with those reported by McDonald \& Hall (1957) and Williams \& Smith (1976). The only other study in which direct estimates of FT casein have been made (Williams \& Smith, 1976) showed that over a wide range of intakes about $70-90 \%$ of FT casein escaped degradation in the rumen. The value found in the present study is clearly 
a considerable overestimate which could be explained if the $N: P$ value of the casein at the abomasum differed from that in the diet due to the release of appreciable quantities of casein-bound $P$ in the abomasum. However, McDonald \& Hall (1957) and Williams \& Smith (1976) considered that such preferential release was unlikely since Rimington \& Kay (1926) had found that the bond between $P$ and the rest of the casein molecule was very resistant to acid hydrolysis and appears to be only very slowly attacked by enzymes, including pepsin (EC 3.4.4.1).

A further source of error could be in the method used for correcting for substances in the solid phase of the digesta which may release inorganic-P (as well as casein-P) on alkaline hydrolysis and therefore increase the apparent casein-P content (McDonald \& Hall, 1957). This correction factor is usually obtained by giving similar diets without the casein supplements. In this study the urea diet was used to obtain a basal value, and it is possible that the levels of potentially interfering substances were lower for this diet than for those containing casein, again leading to overestimated values. McDonald \& Hall (1957) showed that, with sheep given a semi-purified diet in which casein provided $87 \%$ of the $\mathrm{N}$, only $10 \%$ of the casein escaped degradation in the rumen. This estimate was considered to be an overestimate since 'apparent casein- $\mathrm{N}$ ' was measured in the abomasal contents of sheep when casein hydrolysate was given.

Ling \& Buttery (1978) suggested that the use of AEPA as a protozoal marker was invalidated because it was present in substantial quantities in dietary and bacterial material. However, AEPA could not be detected in any of the dietary ingredients used in the present study. Kandatsu \& Horiguchi (1962), Abou Akkada et al. (1968), Ibrahim et al. (1970), Dufva et al. (1982) and Theurer (1982) have also reported that AEPA, estimated by various methods, could not be detected in a wide range of dietary ingredients. However, Cockburn (1982) found AEPA in low concentrations in hay and in three samples (fish meal, soya-bean meal and molassed peat) similar to those used by Ling \& Buttery (1978) although the concentrations found were much lower, probably due to differences in materials and the analytical procedures used for estimating AEPA. The failure of Ibrahim et al. (1970) to detect AEPA in their diets may have been due to their incorrect identification of AEPA using automatic ion-exchange chromatography. Theurer (1982), using a similar technique, also failed to detect AEPA in diets, but neither could he detect it in protozoal or duodenal digesta protein. The problems of analysing AEPA by this procedure have recently been reported by Cockburn \& Williams (1982). AEPA occurs widely in nature (Horiguchi, 1971) and new sources are continually being reported. For example, there have been so many reports of its presence in bovine tissues (Shimizu et al. 1965; Tamari \& Kametaka, 1973; Hasegawa \& Tamari, 1976) that it would be surprising if it were absent from, for example, meat and bone meal. Similarly, since the presence of AEPA has been widely reported in marine organisms such as Antarctic krill (Tamari, 1979), which provide a major food source for fish, its presence in fish meal is not unexpected. It was originally thought that protozoa became established in the rumen by the ingestion of hay and fresh herbage contaminated with ciliate protozoa closely resembling rumen ciliate protozoa (Hungate, 1966). Although it is now known that the two populations are quite different, it may be that the protozoa associated with hay also contain AEPA.

The use of AEPA or any other marker depends upon the assumption that any marker present in the diet is completely degraded in the rumen. Preliminary studies (Cockburn, 1982) have shown that pure AEPA infused into the rumen of both a faunated and defaunated steer disappeared more rapidly than did PEG infused at the same time, and its disappearance could not be correlated with an increase in AEPA content of the microbial population. The rate of disappearance was faster than would be accounted for by digesta flow alone and the AEPA was probably degraded. The AEPA could have been absorbed 
across, or metabolized in, the rumen wall and this would seem likely in view of the absence of AEPA metabolism by rumen digesta in vitro (Cockburn, 1982). Similar differences between in vivo and in vitro results were reported for RNA by McAllan \& Smith (1973).

The finding of this study, that AEPA was present in mixed rumen bacterial preparations, is not unique. There have been two previous reports indicating the presence of AEPA in rumen bacteria (Czerkawski, 1974; Ling \& Buttery, 1978), although the values obtained in the present study $(2 \cdot 25-2 \cdot 31 \mathrm{mg}$ AEPA-N/g TN) were higher than those previously reported (0.21-1.09 mg AEPA-N/g TN). The reasons for the higher levels found in this study are not clear but it is probable that several factors are involved such as differences in animals, diets, microbial populations and in the methods used for analysis of AEPA. On the other hand, Abou Akkada et al. (1968), El Shazly et al. (1975), Hagemeister (1975) and Dufva et al. (1982) failed to detect AEPA in rumen bacteria. AEPA has been detected in non-rumen bacteria such as mycobacteria (Raghupati Sarma et al. 1970), and Kandatsu \& Horiguchi (1962) reported its presence in appreciable quantities in some unspecified bacteria. Some bacteria are known to utilize phosphonates as a source of $\mathrm{C}, \mathrm{P}$ and $\mathrm{N}$ (Lacoste et al. 1976; Cook et al. 1978) but currently the only report of bacterial synthesis of AEPA is that for mycobacteria (Raghupati Sarma et al. 1970) and it has been assumed that AEPA in bacteria originates from some other source. Ling \& Buttery (1978) suggested that this source could be rumen protozoa, endogenous secretions or the diet. In the present investigation, the dietary source may be disregarded. Ling \& Buttery (1978) also reported that bacterial AEPA content was closely correlated with the size of the accompanying ciliate population, but this was not evident from preliminary studies (Cockburn, 1982) using defaunated steers, which showed that similar levels of AEPA were present in rumen bacteria when the ciliates were absent, suggesting that the source of bacterial AEPA was not protozoal. In the latter experiments AEPA was still detected in samples of abomasal digesta $(0 \cdot 12-0 \cdot 20 \mathrm{mg}$ AEPA/g DM) even though protozoa were absent, confirming its presence in rumen bacteria.

The AEPA-N:TN values for protozoal cells were variable, 4.07-7.72 mg AEPA N/g N, but the mean (with SE) value for all observations, 5.41 (0.26), was similar to that reported (3.65) by Landis \& Haselback (1980) for ciliate protozoa isolated from the rumen of the goat and grown in vitro, but somewhat higher than the range of values $(1 \cdot 8-2 \cdot 13)$ reported by Czerkawski (1974), Hagemeister (1975) and Ling \& Buttery (1978), and very different from values of 19.6 and 16.0 reported by Abou Akkada et al. (1968) and Nour et al. (1979) respetively. More recently, Dufva et al. (1982) have reported protozoal AEPA-N:TN values of $1.6 \mathrm{mg} / \mathrm{g}$ and $1.0 \mathrm{mg} / \mathrm{g}$ for steers given high-roughage and high-concentrate diets respectively. The considerable variation in AEPA-N:TN values for rumen ciliate protozoa may be due to species differences (Abou Akkada et al. 1968; Nour et al. 1979), to differences in the levels of storage carbohydrate within the cells (Czerkawski, 1976), to diet effects (Dufva et al. 1982) or to the different analytical procedures used for determining AEPA.

The problems associated with the use of DAPA as a marker for bacterial-N have been extensively reported by Hutton $e t$ al. (1971), Mason \& White (1971) and Ling \& Buttery (1978). In the present study the mean DAPA-N:TN values for mixed rumen bacterial isolates, apart from those when the urea diet was given, were within the range of values (4.7-9.5 mg DAPA-N/g TN) reported by Hutton et al. (1971), Lindsay \& Hogan (1972), Chamberlain et al. (1976), Ling \& Buttery (1978) and Krawielitzki et al. (1978). The higher value of DAPA-N:TN, found in bacteria isolated from steers given urea, may have been due to the presence of different species of bacteria containing higher levels of DAPA (Work \& Dewey, 1953) and/or lower levels of TN. Ibrahim \& Ingalls (1972) have reported higher levels of DAPA in bacteria isolated from cows given urea supplements. On the other hand, Ling \& Buttery (1978) found that dietary ingredients, including urea, had no effect on the 
mean DAPA content of the bacteria and suggested that the considerable variations in individual values of bacterial DAPA were more likely to be due to changes in the rumen microbial population and environment. The presence of sub-optimal levels of nutrients such as $\mathrm{NH}_{3}$ and glucose in the rumen can also have a marked effect upon the composition of the bacteria (Pettipher \& Latham, 1979).

The problems of using RNA as a microbial marker, i.e. the contribution of RNA from undegraded dietary-N to the abomasal digesta RNA and the influence of the protozoa on the RNA procedure, are well known (Smith \& McAllan, 1970; Ling \& Buttery, 1978). The mean RNA-N:TN values of the isolated rumen bacteria in the present study were similar to those reported by Ling \& Buttery (1978). However, they reported considerable variations in the results for individual preparations, and this was also found in the present study. Probably dietary contamination, unrepresentative sampling or analytical error were the major causes of these variations. Smith \& McAllan (1974) reported RNA-N:TN values of $70 \cdot 0-80.0 \mathrm{mg} / \mathrm{g}$ for bacteria isolated from sheep and cows, 4-6 h after feeding. However, bacteria prepared from ciliate-free calves gave a higher value $(108.0 \mathrm{mg} / \mathrm{g})$ when sampled at the same time. They also found that bacteria sampled after feeding were significantly lower in RNA-N:TN than bacteria sampled after feeding in both faunated and defaunated animals. Clearly the RNA-N:TN value of bacteria is influenced by environmental factors in the rumen.

No attempt was made to measure the RNA content of the protozoa in the present study. It has generally been assumed that the RNA-N:TN value for protozoa is similar to that for bacteria (Smith \& McAllan, 1970), but the findings of Czerkawski (1976) and Ling \& Buttery (1978) do not support this view. Although the presence of ciliate protozoa in the rumen has been shown to have a marked effect upon the RNA-N:TN content of the bacteria, the manner of this effect has not been established (Smith \& McAllan, 1974). Ciliate protozoa are known to ingest bacteria and to restrict their numbers (Coleman, 1975). The protozoa have also been shown to have an effect upon the species of bacteria present (Eadie \& Gill, 1971) and their metabolic activity (Kurihara et al. 1968). The presence of protozoa may also lead to a restriction of the nutrients available for bacterial protein synthesis, to the host animal's disadvantage, particularly if the protozoa are selectively retained in the rumen.

digesta obtained by the different chemical markers were compared (Table 10) with those obtained by the modification of the AAP procedure of Evans et al. (1975). The latter method is not devoid of criticism (Siddons et al. 1979) but could assist in assessing the other marker procedures. As has been stated, the marker procedures used in this study must overestimate the contribution of the microbial and dietary components. This is particularly evident for the urea diet, where the sum of these components is highest (1.44), probably due to the very high value for the protozoal contribution ( 0.56 compared with 0.25 by the AAP method). El Shazly \& Naga (1980) also found a high proportion of protozoal-N (0.53) estimated by AEPA in the digesta of sheep given protein-free diets, but unfortunately no other diet was studied. Ling \& Buttery (1978) found that the total sum of the individual $\mathrm{N}$ components in the duodenal digesta of sheep was much higher for the urea-supplemented diet than for those supplemented with fish meal or soya-bean meal. However, the protozoal-N, estimated by AEPA, was not markedly higher for the urea diet.

With the exception of the FT casein diet, comparison of the other values obtained for the proportion of protozoal-N, using AEPA as marker, with those from the AAP procedure confirms that AEPA overestimates this component. The differences between the microbial (RNA) and bacterial (DAPA) components support this view. This is clearly due to the presence of AEPA in rumen bacteria, and the present study confirms the doubts expressed by Ling \& Buttery (1978) on the use of this marker for protozoa. Studies in which the use 
of AEPA has suggested fairly high levels of protozoal-N in digesta leaving the rumen (Ibrahim \& Ingalls, 1972; Hagemeister, 1975; El Shazly \& Naga, 1980) must be regarded as suspect and a reliable alternative marker for protozoa is needed. For example, John \& Ulyatt (1979) have used phosphatidyl choline to estimate protozoal-N at the duodenum of sheep.

Of the other markers, RNA gave higher estimates for the microbial-N contribution compared with those obtained by AAP, except for the FT casein diet. Since there must be some protozoal- $\mathbf{N}$ entering the abomasum together with undegraded dietary- $\mathrm{N}$ and endogenous- $\mathrm{N}$, it seems likely that the RNA-based values are slight overestimates. Estimates of the proportion of bacterial-N using DAPA as a marker are higher than those obtained by AAP and markedly so in the case of the urea and FT casein diets. The latter two profiling results seem unrealistically low and must be considered doutbful. Other workers (Nikolić \& Jovanović, 1973; Smith, 1975; Ling \& Buttery, 1978) have reported that bacterial-N, estimated by DAPA, can give higher levels than the microbial-N, estimated by RNA. In the present study this has only occurred when FT casein was given. The proportion of undegraded dietary casein-N, estimated from the alkaline-labile $\mathrm{P}$ content of the casein, was close to that found by the AAP procedure when UT casein was given. When FT casein was given the direct estimates of casein-N, both as a proportion and in absolute amounts, were much higher than those found by AAP. Since the direct estimates were higher than theoretically possible, as discussed earlier, they must be regarded as incorrect. Each of the procedures used in the present study has been shown to have limitations and, in general, overestimate the contributions of microbial- and dietary- $\mathrm{N}$ in ruminant abomasal digesta. Additional comparative studies of this type and of those of Ling $\&$ Buttery (1978) are needed to establish more satisfactory procedures.

We thank Dr H. L. Buttle for carrying out all surgical operations, Mrs C. P. Chard for supervising the care of the animals, Mrs A. Farmer, Mrs S. Thurston and Miss K. R. Woodsell for their skilled technical assistance and Dr D. Hewitt for advice on statistical analyses. The authors are indebted to Dr R. A. Evans, University College of North Wales, Bangor, for providing advice and information on the AAP procedure and to their colleague $\mathrm{Mr} \mathrm{C}$. Bishop for his help in the use and modification of the procedure. The advice and encouragement of Dr R. H. Smith is gratefully acknowledged.

\section{REFERENCES}

Abou Akkada, A. R. \& Howard, B. H. (1960). Biochemical Journal 76, 445-451.

Abou Akkada, A. R., Messmer, D. A., Fina, L. R. \& Bartley, E. E. (1968). Journal of Dairy Science 51, 78-81. Agricultural Research Council (1980). In The Nutrient Requirements of Ruminant Livestock. Farnham Royal: Commonwealth Agricultural Bureaux.

Bergen, W. G., Purser, D. B. \& Cline, J. H. (1968a). Journal of Dairy Science 51, 1698-1700.

Bergen, W. G., Purser, D. B. \& Cline, J. H. (1968b). Journal of Animal Science 27, 1497-1501.

Buttery, P. J. \& Cole, D. J. A. (1977). Proceedings of the Nutrition Society 36, 211-217.

Chamberlain, D. G., Thomas, P. C. \& Wilson, A. G. (1976). Journal of the Science of Food and Agriculture 27, 231-238.

Chow, R. B. \& Kassel, B. (1968). Journal of Biological Chemistry 243, 1718-1724.

Cochran, W. G. \& Cox, G. M. (1962). Experimental Designs, 2nd ed., p. 50. London and New York: John Wiley \& Sons.

Cockburn, J. E. (1982). The measurement of protozoal protein in the digestive tract of ruminants. M. Phil. Thesis, University of Reading.

Cockburn, J. E. \& Williams, A. P. (1982). Journal of Chromatography 249, 103-110.

Coleman, G. S. (1975). In Digestion and Metabolism in the Ruminant, pp. 149-164 [I. W. McDonald and A. C. I. Warner, editors]. Armidale, NSW, Australia: University of New England Publishing Unit.

Cook, A. M., Daughton, C. G. \& Alexander, M. (1978). Journal of Bacteriology 133, 85-90.

Cottle, D. J. \& Nolan, J. V. (1982). In Animal Production in Australia. Proceedings of the Australian Society of Animal Production, vol. 14, pp. 588-591. Oxford: Pergamon Press. 
Czerkawski, J. W. (1974). Journal of the Science of Food and Agriculture 25, 45-55.

Czerkawski, J. W. (1976). Journal of the Science of Food and Agriculture 27, 621-632.

Dufva, G. S., Bartley, E. E., Arambel, M. J., Galitzer, S. J. \& Dayton, A. D. (1982). Journal of Animal Science 54, 837-840.

Eadie, J. M. \& Gill, J. C. (1971). British Journal of Nutrition 26, 155-167.

El Shazly, K. \& Naga, M. A. (1980). Zeitschrift für Tierphysiologie, Tierernährung und Futtermittelkunde 44, 18.

El Shazly, K., Nour, A. M. \& Abou Akkada, A. R. (1975). Analyst, London 100, 263-268.

Evans, R. A., Axford, R. F. E. \& Offer, N. W. (1975). Proceedings of the Nutrition Society 34, 65A.

Hagemeister, H. (1975). Kieler Milchwirtschaftliche Forschungsberichte 27, 347-354.

Harrison, D. G. \& McAllan, A. B. (1980). In Digestive Physiology and Metaboiism in Ruminants, pp. 205-226 [Y. Ruckebusch and P. Thivend, editors]. Lancaster: MTP Press Ltd.

Harrop, C. J. F. (1974). Journal of Agricultural Science, Cambridge 83, 249-257.

Hasegawa, S. \& Tamari, M. (1976). Agricultural and Biological Chemistry 40, 2097-2098.

Hemsley, J. A., Reis, P. J. \& Downes, A. M. (1973). Australian Journal of Biological Sciences 26, 961-968.

Hoeller, H. \& Harmeyer, T. (1964). Zentralblatt für Veterinärmedizin, Reihe A 3, 244-245.

Horiguchi, M. (1971). In Analytical Chemistry of Phosphorus Compounds, pp. 703-724 [M. Holman, editor]. London: John Wiley \& Sons.

Hungate, R. E. (1966). The Rumen and its Microbes. New York: Academic Press.

Hutton, K., Bailey, F. J. \& Annison, E. F. (1971). British Journal of Nutrition 25, 165-173.

Ibrahim, E. A. \& Ingalls, J. R. (1972). Journal of Dairy Science 55, 971-978.

Ibrahim, E. A., Ingalls, J. R. \& Bragg, D. B. (1970). Canadian Journal of Animal Science 50, 397-400.

John, A. \& Ulyatt, M. J. (1979). Proceedings of the Nutrition Society 38, 144A.

Jouany, J. P. (1978). Contribution à l'étude des protozaires ciliés du rumen: leur dynamique, leur rôle dans la digestion et leur interprêt pour le ruminant. PhD Thesis, University of Clermont-Ferrand.

Journet, M. \& Verité, R. (1979). Annales de Recherches Vétérinaires 10, 303-306.

Kandatsu, M. \& Horiguchi, M. (1962). Agricultural and Biological Chemistry 26, 721-722.

Kaufmann, W. (1977). Proceedings of the 2nd EAAP Symposium on Protein Metabolism and Nutrition, publication no. 22, pp. 130-132. Wageningen, The Netherlands: European Association of Animal Production.

Kirkpatrick, D. S. \& Bishop, S. H. (1971). Analytical Chemistry 43, 1707-1709.

Krawielitzki, R., Piatkowski, B. \& Kreienbring, F. (1978). Archiv für Tierernährung 28, 701-708.

Kurihara, Y., Eadie, J. M., Hobson, P. N. \& Mann, S. O. (1968). Journal of General Microbiology 51, 267-288.

Lacoste, A., Cassaigne, A., Tamari, M. \& Neuzil, E. (1976). Biochimie 58, 703-712.

Landis, J. \& Haselback, C. (1980). Proceedings of the 3rd EAAP Symposium on Protein Metabolism and Nutrition, publication no. 27, pp. 489-495 [H. J. Oslage and K. Rohr, editors]. Braunschweig, Fed. Rep. Germany: European Association of Animal Production.

Lindsay, J. R. \& Hogan, J. P. (1972). Australian Journal of Agricultural Research 23, 321-330.

Ling, J. R. \& Buttery, P. J. (1978). British Journal of Nutrition 39, 165-179.

McAllan, A. B. \& Smith, R. H. (1969). British Journal of Nutrition 23, 671-682.

McAllan, A. B. \& Smith, R. H. (1972). Proceedings of the Nutrition Society 31, 24A.

McAllan, A. B. \& Smith, R. H. (1973). British Journal of Nutrition 29, 331-345.

McAllan, A. B. \& Smith, R. H. (1983). British Journal of Nutrition 49, 119-128.

McDonald, I. W. \& Hall, R. J. (1957). Biochemical Journal 67, 400-405.

MacGregor, C. A., Sniffen, C. J. \& Hoover, W. H. (1978). Journal of Dairy Science 61, 566-673.

Mason, V.S., Bech-Andersen, S. \& Rudemo, M. (1980). Zeitschrift für Tierphysiologie, Tierernährung und Futtermittelkunde 43, 146-164.

Mason, V. S. \& Palmer, R. (1971). Journal of Agricultural Science, Cambridge 76, 567-572.

Mason, V. S. \& White, F. (1971). Journal of Agricultural Science, Cambridge 71, 91-98.

Mathers, J. C., Thomas, R. J., Gray, N. A. M. \& Johnson, I. L. (1979). Proceedings of the Nutrition Society 38, $122 \mathrm{~A}$.

Mercer, J. R., Allan, S. A. \& Miller, E. L. (1980). British Journal of Nutrition 43, 421-433.

Merry, R. J. (1980). The use of dietary non-protein nitrogen compounds by the ruminant with particular emphasis on the glycosyl ureides. PhD Thesis, University of Reading.

Meyer, R. H., Bartley, E. E., Deyoe, C. W. \& Colenbrander, V. F. (1967). Journal of Dairy Science 50, 1327-1332.

Nikolić, A. \& Jovanović, M. (1973). Journal of Agricultural Science, Cambridge 81, 1-7.

Nour, A. M., El Shazly, K., Abou Akkada, A. R., Naga, M. A. \& Borhami, B. E. (1979). Alexandria Journal of Agricultural Research 27, 113-120.

Offer, N. W., Axford, R. F. E. \& Evans, R. A. (1978). British Journal of Nutrition 40, 35-44.

Ørskov, E. R. \& MacLeod, N. A. (1982). British Journal of Nutrition 47, 625-636.

Pettipher, G. \& Latham, M. J. (1979). Journal of General Microbiology 110, 29-38.

Potter, E. L. \& Dehority, B. A. (1973). Applied Microbiology 26, 692-698.

Purser, D. B. \& Buechler, S. M. (1966). Journal of Dairy Science 49, 81-84.

Raghupati Sarma, G., Chandramouli, V. \& Venkita Subramanian, T. A. (1970). Biochimica et Biophysica Acta 218, 561-563.

Rimington, C. \& Kay, H. D. (1926). Biochemical Journal 20, 777-790. 
Roy, J. H. B., Balch, C. C., Miller, E. L., Ørskov, E. R. \& Smith, R. H. (1977). Proceedings of the 2nd EAAP Symposium on Protein Metabolism and Nutrition, publication no. 22, pp. 126-129. Wageningen, The Netherlands: European Association of Animal Production.

Satter, L. D. \& Roffler, R. E. (1977). Journal of Dairy Science 58, 1219-1237.

Shimizu, H., Kakimoto, T., Nakajima, T., Kanazawa, A. \& Sano, I. (1965). Nature 207, 1198.

Siddons, R. C., Beever, D. E., Nolan, J. V., McAllan, A. B. \& MacRae, J. C. (1979). Annales de Recherches Vétérinaires 10, 286-287.

Smith, R. H. (1975). In Digestion and Metabolism in the Ruminant, pp. 399-415 [I. W. McDonald and A. C. I. Warner, editors]. Armidale, NSW, Australia: University of New England Publishing Unit.

Smith, R. H. (1983). In Proceedings of the Sixth International Symposium on Amino Acids, Serock, Poland.

Smith, R. H. \& McAllan, A. B. (1970). British Journal of Nutrition 24, 545-556.

Smith, R. H. \& McAllan, A. B. (1971). British Journal of Nutrition 25, 181-190.

Smith, R. H. \& McAllan, A. B. (1974). British Journal of Nutrition 31, $27-34$.

Smith, R. H., McAllan, A. B., Hewitt, D. \& Lewis, P. E. (1978). Journal of Agricultural Science, Cambridge 90, $557-568$.

Spackman, D. H., Stein, W. H. \& Moore, S. (1958). Analytical Chemistry 30, 1190-1205,

Synge, R. L. M. (1953). Journal of General Micorobiology 9, 407-409.

Tamari, M. (1979). Agricultural and Biological Chemistry 43, 651-652.

Tamari, M. \& Kametaka, M. (1973). Agricultural and Biological Chemistry 37, 933-935.

Tas, M. V., Evans, R. A. \& Axford, R. F. E. (1981). British Journal of Nutrition 45, 167--174.

Technicon Instruments Corporation (1967). Technicon Method Sheet N-3b, Tarrytown, New York: Technicon Instruments Corporation.

Theurer, C. B. (1982). In Protein Requirements for Cattle: Symposium 1980, pp. 10-22 [F. N. Owen, editor]. Stillwater, Oklahoma: Oklahoma State University.

Ulyatt, M. J., MacRae, J. C., Clark, R. T. J. \& Pearce, P. D. (1975). Journal of Agricultural Science, Cambridge 84, 453-458.

Valdez, R. E., Alvarez, F. J., Ferreiro, H. M., Guerra, F., Lopez, J., Priego, A., Blackburn, T. H., Leng, R. A. \& Preston, T. R. (1977). Tropical Animal Production 2, 260-272.

Wakita, M. \& Hoshino, S. (1979). Japanese Journal of Zootechnical Science 50, 1-7.

Warner, A. C. I. (1962). Journal of General Microbiology 28, 119-128.

Weller, R. A. (1957). Australian Journal of Biological Science 10, 384-389.

Williams, A. P. (1974). Amino acid requirements of the young bovine. PhD Thesis, University of Reading.

Williams, A. P. \& Smith, R. H. (1974). British Journal of Nutrition 32, 421-433.

Williams, A. P. \& Smith, R. H. (1976). British Journal of Nutrition 36, 199-209.

Williams, P. P. \& Dinusson, W. E. (1973). Journal of Animal Science 36, 588-591.

Work, E. \& Dewey, A. L. (1953). Journal of General Microbiology 9, 394-409. 